\title{
Needs, Interests, Enablers and Barriers to Professional Development: Findings from the Nepalese EFL Teachers
}

\author{
Kumari Damayanti Joshi ${ }^{1,}$, Laxman Gnawali ${ }^{2}$, Ram Ashish Giri ${ }^{3}$, Diane Mayer ${ }^{4}$ \& Mary Dixon ${ }^{5}$ \\ ${ }^{1}$ School of Education and Arts, Deakin University, Melbourne, Australia \\ ${ }^{2}$ School of Education, Kathmandu University, Nepal \\ ${ }^{3}$ English Languages Centre, Monash University, Melbourne, Australia \\ ${ }^{4}$ Harris Manchester College, The University of Oxford, Oxford, UK \\ ${ }^{5}$ School of Education and Arts, Deakin University, Melbourne, Australia \\ *Correspondence: School of Education and Arts, Deakin University, Melbourne, Australia. E-mail: \\ zosi.diya@gmail.com
}

Received: December 24, 2021

Accepted: January 10, 2022 Online Published: January 19, 2022

doi:10.5430/ijelt.v9n1p25

URL: https://doi.org/10.5430/ijelt.v9n1p25

\begin{abstract}
Professional development for English as a Foreign Language (EFL) teachers has gained increasing relevance worldwide. This study reports on issues of Nepalese EFL teachers' professional development (needs, interests, enablers and barriers). Data from 257 EFL teachers were used to assess and explore these issues. Quantitative data were used to describe the needs, interests and their relationships with the teachers' socio-demographics; while qualitative data were used for exploring the enablers of and barriers to teacher professional development. More than half of the teachers reported their professional development needs for various instructional skills to be high to very high. Similarly, more than two thirds of the teachers reported their PD interests for all professional development activities to be high to very high. The EFL teachers also highlighted a number of environmental, institutional and personal enabling and challenging factors in pursuing their professional development. This study concludes that Nepalese EFL teachers demonstrated a considerable need of and interest in TPD despite experiencing several types of challenges.
\end{abstract}

Keywords: EFL teachers, Nepal, professional development interest, professional development needs, teacher professional development

\section{Introduction}

Teachers' professional development (TPD) involves several approaches such as formal education, credentialing, in-service training, mentoring, etc., and is one of the most critical efforts in improving education systems (Darling-Hammond \& Richardson, 2009). TPD aims to strengthen teachers' learning and skills, and translate them into enhancing students' academic achievement (Vescio, Ross \& Adams, 2008).

The reviews on TPD (Avalos, 2011; Popova et al. 2018) show that a vast majority of TPD activities and TPD-associated research mainly takes place in developed countries. This has substantially contributed to the understanding of TPD and its characteristics. For example, the surveys conducted in the US and Australia have shown that teachers face a number of challenges in their pursuit of TPD (NSW Education Standards Authority, 2017; the Bill \& Melinda Gates Foundation, 2014). Some of these challenges are universal (e.g., funding and support from school) while others are more specific to a country (NSW Education Standards Authority, 2017; the Bill \& Melinda Gates Foundation, 2014). However, understanding of TPD (e.g., interests and needs), including enablers and barriers to TPD from developing countries is limited. Poor co-ordination, lack of resources and a substantial focus on pre-service teacher education are some of the challenges to TPD in developing countries (Leu, 2004; Dayoub \& Bashiruddin, 2012; Asian Development Bank, 2017). As a result, implementation of TPD programs in developing countries are likely to face a number of challenges. Despite these odds, development and implementation of TPD 
programs in developing countries are ongoing (Khan, 2015; Komba \& Nkumbi, 2008; Mohan \& Chand, 2017; Shrestha, 2012; Zein, 2016; Asian Development Bank, 2017, McAleavy et al., 2018).

Recently, there is a growing recognition that role of teachers in the development and implementation of TPD programs should be considered. This would help in knowing real needs and interests of teachers and addressing them through prospective TPD programs accordingly (Blase \& Blase 1999; Garet et al., 2001). For example, understanding of needs and interests of teachers in relation to TPD helps in designing and implementing need-based TPD programs. It can be argued that such programs are more likely to be accepted by teachers in matching their needs and interests rather than those implemented with a top-down approach. Need-based TPD programs are considered more sensible and effective in bringing about the positive academic outcomes (c.f., Badri et al., 2016). Therefore, a thorough understanding of the issues of TPD (e.g., interests, needs, challenges, etc.) is important to design a need-based TPD program. The understanding of teachers' issues on professional development has been known to some extent. For example, assessment of professional development issues has been conducted in some countries, such as Abu Dhabi (Badri et al., 2016), China (Lin, 2013), Indonesia (Zein, 2016), Malaysia (Khandehroo et al., 2011), and Turkey (Korkmazgil \& Seferoğlu, 2013). These data have put some light on what kind of professional development program teachers need, what level of interest teachers show towards those programs, and what factors encourage or discourage teachers in pursuing such activities. However, there is paucity of such comparable data from several developing countries, including Nepal (Asian Development Bank, 2017).

\section{Study Context and Aim}

In Nepal, the National Centre for Educational Development (NCED) within the Ministry of Education is responsible agency for delivering the largest segment of in-service TPD programs to the teachers from primary to higher secondary schools (Asian Development Bank, 2017). The NCED has a total of 34 education training centres (ETCS) across the country. In addition, a few private and non-governmental organizations involving in TPD seem to exist in the country; however, there is no official data on them (Asian Development Bank, 2017). The detailed evolution of TPD programs in Nepal is discussed elsewhere (Joshi et al., 2018).

The Government of Nepal implemented the School Sector Reform Plan (SSRP, 2009-2016) to strengthen qualification and competencies of public-school teachers and improving students' learning outcomes (Ministry of Education, 2009). The SSRP recognised the importance of need-based teacher trainings in Nepal, and hence delivered the TPD trainings based on local needs of teachers. However, a detailed and systematic assessment of TPD needs and interests of teachers was never conducted. Despite the attempt of the SSRP to address needs of teachers in relation to their TPD, the quality of TPD sessions and their outcomes in improving students' learning were questionable (Shams et al., 2012).

The TPD programs, including those included in the SSRP, were mainly provided to permanent teachers in public schools (Ministry of Education, 2013). Therefore, the programs excluded private schools (share 17\% the total schools) in Nepal (Ministry of Education, 2016a). The TPD program within the SSRP (2009-2016), which for the first time included need-based trainings, provided with three 10-day TPD modules, each involving face-to-face training and school-based action research (Asian Development Bank, 2017). The School Sector Development Plan, SSDP (2016-2023) is currently being implemented in the country (Ministry of Education, 2016b). The SSDP also has TPD as one of its themes with a focus on need-based TPD programs. This shows Nepalese government's interest in implementing need-based TPD programs.

It is obvious that teachers in Nepal, including English as a Foreign Language (EFL) teachers, have limited training opportunities (Aryal et. al, 2016; Ministry of Education, 2010; Shrestha, 2008). The poor performance in English language by the students of public schools (Ministry of Education, 2014) is regarded as one of the consequences of inadequate TPD opportunities for EFL teachers. This is important as more than $80 \%$ of total student enrolments in schools are shared by public schools (Department of Education, 2012). Therefore, Nepalese EFL teachers should be supported with on-going adequate and relevant TPD programs, as indicated by several studies (Adhikari, 2011; Bharati \& Chalise, 2017; Joshi et al., 2016; Joshi, 2010, Pokhrel \& Behera, 2016; Shah, 2015). Such programs should be built upon the adequate evidence of their needs, interests, and their perception of enablers and barriers to TPD. However, up until now, no such assessment was conducted, including that for EFL teacher (Asian Development Bank, 2017).

The overall purpose of this study was to identify and evaluate PD needs, interests, enablers and barriers to TPD among Nepalese EFL teachers. The research questions were: i) what are the professional development needs of 
Nepalese EFL teachers, and what TPD activities are they interested in pursuing?, iii) what are enablers and barriers to teacher professional development programs for the EFL teachers?, iv) what are their perceptions towards the usefulness of any incentive or support the teachers receive while pursuing TPD programs?, iv) what are relationships between the TPD needs, interests, and engagement, and the teachers' socio-demographic factors?

\section{Methodology}

\subsection{Study Design and Participants}

This is a descriptive study that was carried out using a convenience sample of Nepalese EFL teachers attending the $21^{\text {st }}$ international conference of Nepal English Language Teachers Association (NELTA), 7-9 March 2016, Kathmandu. NELTA is a professional organisation of private and public-school English language teachers with about 3,000 life members (Gnawali, 2016). Of 739 Nepalese EFL teachers, who were invited to fill out the questionnaire, 327 provided their responses (44\% response rate). Following careful screening of the responded questionnaires, 70 of them had incomplete information. Therefore, the final study sample consisted of 257 participants.

\subsection{Data Collection}

A modified form of semi-structured and self-administered questionnaire (Kohl, 2005) was used in this study. Kohl's (2005) questionnaire has also been used elsewhere (Korkmazgil \& Seferoğlu; 2013; Khandehroo et al., 2011; Anderson, 2008). We validated the questionnaire in Nepalese setting by testing it. The questionnaire was tested among student teachers of English Language Education at School of Education, Kathmandu University. Upon revising the test questionnaire, the final study questionnaire was designed.

The study questionnaire was prefaced with an explanatory statement and distributed to the NELTA participants along with the NELTA conference pack, requesting them to take part voluntarily. The study received a written consent from the NELTA executive committee, and each participant also filled out the provided consent form along with the questionnaire.

The $1^{\text {st }}$ section of the questionnaire collected information on the teacher's socio-demographic and teaching characteristics: sex, age-group, highest qualification, EFL teaching experience, teaching level (e.g., primary, secondary or higher education), and institute type (e.g., private, public, or both), teacher's individual needs of professional development in the area of English language teaching (ELT), teacher's reported professional development needs in relation to instructional skills, level of interest for different general TPD activities, etc. Further, we also collected data on the TPD needs for specific instructional skills (e.g., classroom management, the use of information and communication technology, language and pedagogic skills, student assessment, using cooperative learning, etc.). Similarly, teachers' reported interests for different general TPD activities were also collected. The participants' information on the TPD needs and interests were collected in the 6-point Likert scale ('very high', 'high', 'moderate', 'low', 'no', and 'not applicable'). Plus, data on the incentives/types of support (i.e., release time, financial support, advancement on the pay scale, on-site access to resources, and on-site workshops) that teachers received from their institute and district education office for pursuing TPD programs were also collected. The data on teachers' reported usefulness of TPD was grouped into the 5-point Likert scale: most helpful, helpful, moderately helpful, little helpful, not helpful at all, and not applicable. This information was collected for each incentive or support in pursuing TPD programs.

The $2^{\text {nd }}$ section contained two open-ended questions: i) what are key challenges to the professional development of a Nepalese EFL teacher?, and ii) what other key information you would like to share regarding professional development of an EFL Teacher in Nepal? These questions mainly aimed to explore EFL teachers' views on enablers and challenges to pursue professional development programs.

\subsection{Data Analysis}

The quantitative data were entered and coded into SPSS statistical software. The teachers' socio-demographic data were categorised in terms of gender, age groups, educational background, teaching experience, affiliation and professional development needs for ELT. Teachers' experience in EFL teaching was grouped into novice ( $<5$ years) and experienced ( $\geq 5$ years) (Tsui, 2005). Teachers' highest qualification was also grouped into three categories: bachelor's degree or less (higher secondary level/less, BEd or BA), master's degree (MA, MEd, or MPhil), and PhD. The descriptive data on teachers' socio-demographic information, the TPD needs for specific instructional skills, the TPD interests for different general professional development activities, etc. were analysed using descriptive statistics 
(frequency and per cent). The relationship between the socio-demographics and the TPD needs and interests, TPD-related incentives or support they received, and perceived usefulness of each incentive or support in pursuing their professional development were examined by performing Pearson Chi-square tests. The results of perceived usefulness of incentive or support were presented in the section of enablers of TPD. P-value $\leq 0.05$ (both sided) was considered as statistically significant. The data analysis was performed with SPSS (version 22, IBM Corp, Armonk, NY, USA).

The responses from the open-ended questions were analysed using qualitative inductive approach (Leech \& Onwuegbuzie, 2007). The responses were read thoroughly and different codes were generated depending on what the participants said. From the codes, a number of themes and categories were formed. Qualitative findings, in terms of representative quotes from teacher respondents, were presented with their gender and affiliated school type(s) to facilitate the meanings and contexts of the responses. Thematic analysis was performed using the framework of Ecological model proposed by Broffenbrenner (Moreno-Peral et al., 2015). The ecological model considers teachers as individuals affected by several contexts and interrelated processes. The model has recently been used in understanding experiences and motivation of Spanish EFL teachers in teacher professional learning and development (Gadella Kamstra, 2021). In fact, the model takes into account a combined role of classroom and teaching ecosystem context in harnessing teachers' professional learning and development programs. Figure 1 shows various factors (e.g., barriers and enablers) that could affect EFL teachers' professional development in this study context. The model consists of three key levels and associated factors; micro level (e.g., intrapersonal and interpersonal factors), meso level (e.g., institutional factors) and macro level (e.g., environmental factors).

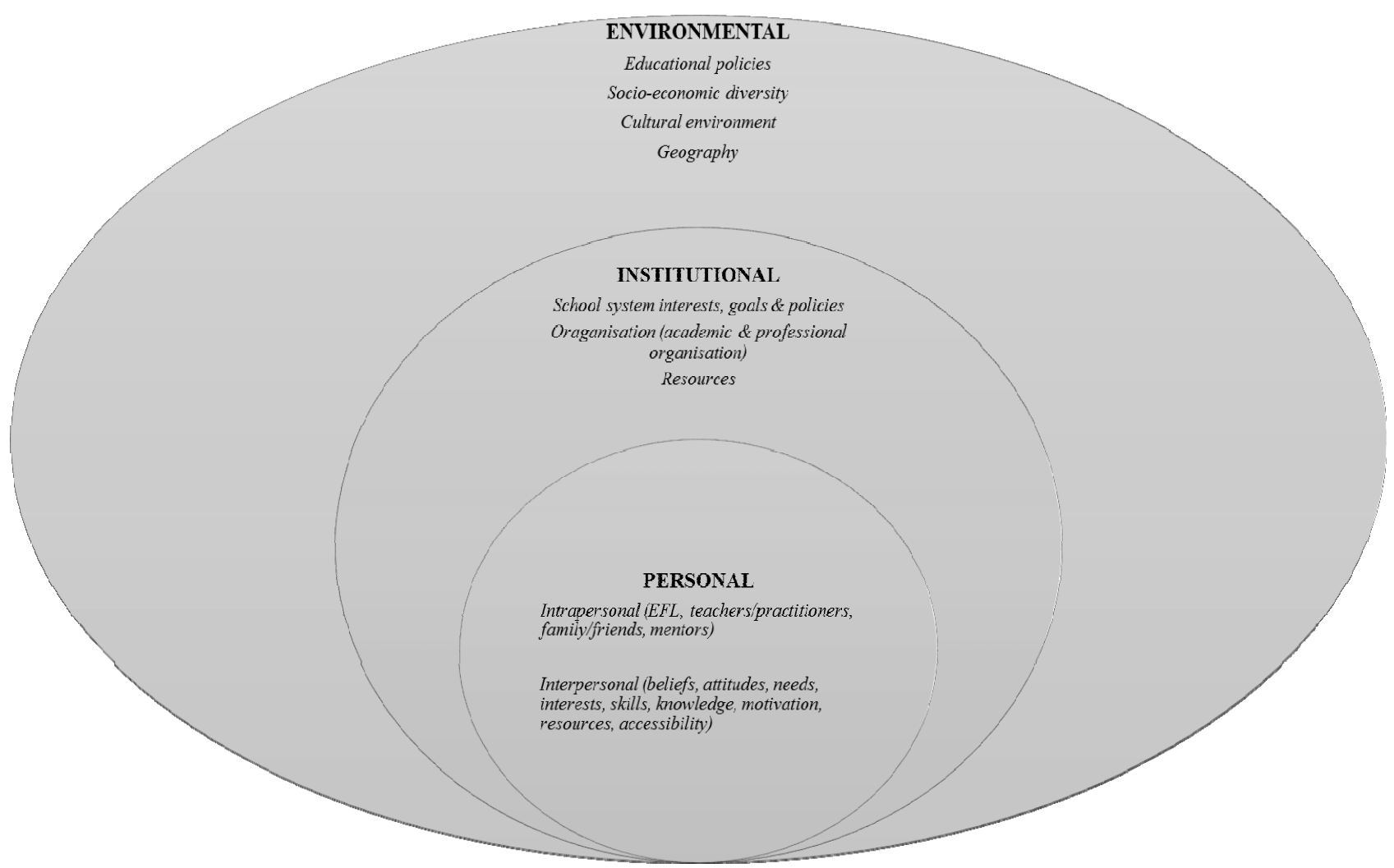

Figure 1. A 3-level Ecological Model Consisting Environmental, Institutional and Personal Factors Affecting EFL Teachers' Professional Development 


\section{Results}

\subsection{Teacher Characteristics}

Of all respondents, four were non-native speakers of English language and were excluded from the data analysis. More than half $(56 \%)$ of the participants were males. Nearly $50 \%$ of the participants were from province 3 , followed by $13.2 \%$ (province 4), 12.7 (province 2), $(\mathrm{n}=25), 10.3$ (province 5 ), $\sim 7.0 \%$ (province 1), 2.9\% (province 7 ), and $1.2 \%$ (province 6$)$.

Table 1. Participants' ( $n=257)$ Socio-Demographic and Teaching Characteristics

\begin{tabular}{|c|c|}
\hline Teachers' characteristics (variables) & Percentage $(\%)$ \\
\hline \multicolumn{2}{|l|}{ Sex } \\
\hline Males & $56 \%$ \\
\hline \multicolumn{2}{|l|}{ Age group (years) } \\
\hline $21-29$ & $47 \%$ \\
\hline $30-39$ & $32 \%$ \\
\hline $40-49$ & $15 \%$ \\
\hline \multicolumn{2}{|l|}{ Qualification(highest) } \\
\hline MEd & $36 \%$ \\
\hline BEd & $21 \%$ \\
\hline MA & $18 \%$ \\
\hline \multicolumn{2}{|l|}{ Teaching level } \\
\hline Primary schools & $26 \%$ \\
\hline Secondary schools & $54.5 \%$ \\
\hline Higher education & $19.5 \%$ \\
\hline \multicolumn{2}{|l|}{ Experience in English teaching (years) } \\
\hline $1-5$ & $38 \%$ \\
\hline $6-10$ & $28 \%$ \\
\hline $11-15$ & $16.5 \%$ \\
\hline $16-20$ & $8.5 \%$ \\
\hline $21-25$ & $4 \%$ \\
\hline 25 plus & $5 \%$ \\
\hline \multicolumn{2}{|l|}{ Institution type } \\
\hline Private & $53 \%$ \\
\hline Public & $34 \%$ \\
\hline Private \& public & $13 \%$ \\
\hline \multicolumn{2}{|l|}{ Employment status } \\
\hline Full-time & $83 \%$ \\
\hline Part-time ( $>50 \%$ of full-time hours) & $13 \%$ \\
\hline Part-time $(<50 \%$ of full-time hours $)$ & $4 \%$ \\
\hline \multicolumn{2}{|l|}{ Teaching license type } \\
\hline Permanent secondary & $67 \%$ \\
\hline Permanent primary & $12 \%$ \\
\hline Temporary secondary & $5 \%$ \\
\hline Temporary primary & $1 \%$ \\
\hline No license & $15 \%$ \\
\hline \multicolumn{2}{|c|}{ Membership to teacher professional organisations } \\
\hline Yes & $59 \%$ \\
\hline No & $41 \%$ \\
\hline
\end{tabular}


Table 1 summarises teachers' data on socio-demographic and teaching characteristics. More than half of the teachers were affiliated with private institutes. Slightly more than $54 \%$ of teachers taught in secondary levels. A vast majority of teachers $(83 \%)$ were working full-time. Fifty-six per cent of teachers had teaching experience in the range of 1-10 years (38\% taught for 1-5 years). Sixty-two per cent were experienced teachers. Thirty-five per cent taught in more than one institute.

\subsection{Engagement in TPD Activities and Incentives or Support}

During the year prior to the survey, $60 \%$ of teachers participated in some form of general and ELT- related professional development activities. Of 152 teachers participating in general PD activities, $95 \%$ of them found those activities greatly or somewhat helped them to improve their teaching practice. Similarly, of 156 teachers participating in ELT related professional development activities, 95\% of them reported that the TPD activities greatly or somewhat helped them to improve their teaching practice. The proportion of the teachers $(\mathrm{n}=255)$ taking part in some form of general and ELT related TPD activities in the last three years was $73 \%$.

A majority of teachers were provided with some financial support (all expenses, $n=26$; most expenses, $n=14$; some expenses, $n=68$ ) by their institute or district education office to attend conferences/seminars/workshops. Of those who did not receive any support, most of them reported that they definitely would or might have attended the conferences/seminars/workshops, had they received some financial support. Of the teachers $(n=248)$, who were asked if their administrators (at institute/district level) support them in meeting their professional development needs, their responses were: completely supportive (30\%), somewhat supportive $(53 \%)$, not so supportive (12\%), not sure/not applicable (5\%).

Sixty-two per cent $(n=147)$ teachers said that they were benefited from the release time offered to them by their school/district education office to attend TPD programs. Less than one-third of the teachers were provided with financial support from their school/district education office to attend the programs. However, $83 \%(n=196)$ of the teachers perceived financial support could have enabled them to attend TPD. Only $36 \%(n=83)$ of the teachers were offered online resource access and onsite workshops. Nearly $80 \%(n=187)$ of the teachers' had online resource access and attended onsite workshops in their TPD.

\subsection{Characteristics of TPD Needs}

Table 2. Teachers' $(n=257)$ Level of PD Needs for Specific Instructional Skills

\begin{tabular}{|c|c|c|c|c|c|c|}
\hline \multirow[t]{2}{*}{ Instructional skills $\left(\mathrm{n}^{+}\right)$} & \multicolumn{6}{|c|}{ Level of needs (percentage) } \\
\hline & very high & high & moderate & low & no & not applicable \\
\hline $\begin{array}{l}\text { Content \& performance standard in main subject } \\
(\mathrm{n}=254)\end{array}$ & $24 \%(n=62)$ & $42 \%(n=106)$ & $27.5 \%(n=70)$ & $4 \%(n=10)$ & $2 \%(n=5)$ & $0.5 \%(\mathrm{n}=1)$ \\
\hline Maintaining my language skills ( $\mathrm{n}=255$ ) & $25 \%(\mathrm{n}=63)$ & $35 \%(\mathrm{n}=90)$ & $28.5 \%(\mathrm{n}=72)$ & $8 \%(n=21)$ & $3 \%(n=8)$ & $0.5 \%(\mathrm{n}=1)$ \\
\hline $\begin{array}{l}\text { Building my awareness } \\
\text { target-culture/multicultural education }(n=253)\end{array}$ & $18.5 \%(\mathrm{n}=47)$ & $38 \%(\mathrm{n}=96)$ & $27 \%(\mathrm{n}=69)$ & $13 \%(n=33)$ & $3 \%(n=7)$ & $0.5 \%(\mathrm{n}=1)$ \\
\hline Working with native English speakers $(\mathrm{n}=254)$ & $29.5 \%(\mathrm{n}=75)$ & $29 \%(\mathrm{n}=72)$ & $28 \%(n=72)$ & $7 \%(n=18)$ & $4 \%(n=10)$ & $2.5 \%(n=6)$ \\
\hline Using cooperative learning $(\mathrm{n}=257)$ & $30 \%(\mathrm{n}=76)$ & $36 \%(\mathrm{n}=92)$ & $23 \%(n=60)$ & $8 \%(n=21)$ & $2 \%(n=6)$ & $1 \%(n=2)$ \\
\hline Student assessment $(\mathrm{n}=253)$ & $22 \%(\mathrm{n}=55)$ & $43 \%(n=108)$ & $24 \%(\mathrm{n}=60)$ & $9 \%(n=22)$ & $3 \%(n=8)$ & - \\
\hline Classroom management $(\mathrm{n}=254)$ & $25 \%(\mathrm{n}=64)$ & $37.5 \%(\mathrm{n}=95)$ & $24.5 \%(\mathrm{n}=62)$ & $9 \%(n=23)$ & $3 \%(n=8)$ & $1 \%(n=2)$ \\
\hline Student discipline $\&$ behaviour problems $(\mathrm{n}=256)$ & $20 \%(\mathrm{n}=51)$ & $34 \%(\mathrm{n}=88)$ & $27 \%(\mathrm{n}=68)$ & $13 \%(\mathrm{n}=33)$ & $5 \%(n=13)$ & $1 \%(n=3)$ \\
\hline Planning lessons \& units $(\mathrm{n}=256)$ & $23 \%(\mathrm{n}=59)$ & $28.5 \%(\mathrm{n}=73)$ & $26.5 \%(\mathrm{n}=67)$ & $14 \%(\mathrm{n}=36)$ & $7 \%(\mathrm{n}=18)$ & $1 \%(n=3)$ \\
\hline $\begin{array}{l}\text { Using Information \& communications technology } \\
(\mathrm{n}=256)\end{array}$ & $35.5 \%(\mathrm{n}=91)$ & $35 \%(n=90)$ & $21 \%(n=54)$ & $5 \%(\mathrm{n}=13)$ & $3 \%(n=7)$ & $0.5 \%(\mathrm{n}=1)$ \\
\hline $\begin{array}{l}\text { Practice of English language teaching } \\
\text { methodologies }(\mathrm{n}=253)\end{array}$ & $28 \%(\mathrm{n}=71)$ & $44.5 \%(n=113)$ & $15 \%(n=39)$ & $9 \%(\mathrm{n}=22)$ & $3 \%(n=7)$ & $0.5 \%(\mathrm{n}=1)$ \\
\hline $\begin{array}{l}\text { Applying English language teaching standards } \\
(\mathrm{n}=254)\end{array}$ & $27 \%(n=68)$ & $40 \%(n=102)$ & $25 \%(n=63)$ & $7.5 \%(n=20)$ & $0.5 \%(n=1)$ & - \\
\hline Teaching students with special needs $(\mathrm{n}=255)$ & $30 \%(n=77)$ & $32.5 \%(n=83)$ & $23.5 \%(n=60)$ & $9.5 \%(n=24)$ & $3 \%(n=7)$ & $1.5 \%(n=4)$ \\
\hline Student counselling $(\mathrm{n}=256)$ & $31 \%(\mathrm{n}=79)$ & $33 \%(\mathrm{n}=85)$ & $26 \%(n=66)$ & $6 \%(n=16)$ & $3 \%(n=8)$ & $1 \%(n=2)$ \\
\hline
\end{tabular}

$\mathrm{n}^{+}=$number of teachers 
Table 2 summarizes teachers' TPD needs according to various type of specific instructional skills. More than $80 \%$ of the teachers reported their TPD needs for all instructional skills to be moderate to very high. Likewise, more than $50 \%$ of the teachers reported their professional development needs for those instructional skills to be high to very high.

Very high TPD need was reported by $30 \%$ or more teachers for using information and communications technology, student counselling, using cooperative learning, and teaching students with special needs. Similarly, high PD need was reported by more than one third of the teachers for all instructional skills, except for planning lessons and units, and working with native English speakers.

\subsection{Teachers' Professional Development (PD) Interests}

Table 3 summarizes teachers' level of PD interests according to various PD activities. More than $86 \%$ of the teachers reported their PD interests for all the PD activities to be moderate to very high. Likewise, more than $72 \%$ of the teachers reported their PD interests for all the PD activities to be high to very high.

Three PD activities in which more than half of the teachers showed very high interest were: getting support from more experienced teachers (mentorship), attending professional conferences/seminars, and participating in in-school or district sponsored-workshops/PD activities. Similarly, three PD activities that reported to have drawn high interest amongst $41 \%$ or more of the teachers were: collaborating with other teachers, participating in out-of-school workshops/courses, and observing other teachers' classes (peer observation).

Table 3. Teachers' $(\mathrm{n}=257)$ Level of Personal Interests for PD Activities

\begin{tabular}{|c|c|c|c|c|c|c|}
\hline \multirow[t]{2}{*}{ Instructional skills (n) } & \multicolumn{6}{|c|}{ Level of teachers' interests in TPD activities } \\
\hline & very high & high & Moderate & low & no & not applicable \\
\hline $\begin{array}{l}\begin{array}{l}\text { Participating } \\
\text { sponsored- } \\
(\mathrm{n}=257)\end{array} \\
\text { workshops/PD activities }\end{array}$ & $50 \%(\mathrm{n}=128)$ & $36 \%(n=93)$ & $11 \%(n=28)$ & $1 \%(n=2)$ & $2 \%(\mathrm{n}=5)$ & $0.5 \%(\mathrm{n}=1)$ \\
\hline $\begin{array}{l}\text { Participating in } \quad \text { out-of-school } \\
\text { workshops/courses }(n=256)\end{array}$ & $39.5 \%(n=101)$ & $41.5 \%(n=106)$ & $16 \%(\mathrm{n}=41)$ & $2 \%(n=5)$ & $0.5 \%(\mathrm{n}=1)$ & $1 \%(n=2)$ \\
\hline $\begin{array}{l}\text { Qualification programs (e.g., degree } \\
\text { program })(n=256)\end{array}$ & $37 \%(n=94)$ & $33 \%(n=84)$ & $21.5 \%(\mathrm{n}=55)$ & $5.5 \%(n=14)$ & $2 \%(n=6)$ & $1 \%(n=3)$ \\
\hline $\begin{array}{l}\text { Attending professional } \\
\text { conferences } / \text { seminars }(n=256)\end{array}$ & $52 \%(\mathrm{n}=133)$ & $36 \%(n=92)$ & $10 \%(\mathrm{n}=25)$ & $1 \%(n=3)$ & $1 \%(n=3)$ & - \\
\hline $\begin{array}{l}\text { Participating in a network of teachers } \\
\text { formed } \\
\text { especially for } \mathrm{PD}(\mathrm{n}=255)\end{array}$ & $47 \%(n=120)$ & $39 \%(n=100)$ & $10.5 \%(\mathrm{n}=27)$ & $1 \%(\mathrm{n}=3)$ & $1 \%(\mathrm{n}=3)$ & $0.5 \%(\mathrm{n}=1)$ \\
\hline $\begin{array}{l}\text { Reading research about English teaching } \\
(\mathrm{n}=256)\end{array}$ & $39 \%(n=100)$ & $40.5 \%(n=104)$ & $16 \%(n=42)$ & $2.5 \%(\mathrm{n}=6)$ & $1 \%(\mathrm{n}=2)$ & $1 \%(\mathrm{n}=2)$ \\
\hline Travelling/studying abroad $(\mathrm{n}=256)$ & $47 \%(n=121)$ & $26 \%(n=66)$ & $14 \%(n=35)$ & $6.5 \%(n=17)$ & $2 \%(n=6)$ & $4.5 \%(\mathrm{n}=11)$ \\
\hline Collaborating with other teachers $(\mathrm{n}=253)$ & $42.5 \%(n=107)$ & $43 \%(n=109)$ & $10 \%(\mathrm{n}=25)$ & $4 \%(n=11)$ & - & $0.5 \%(\mathrm{n}=1)$ \\
\hline $\begin{array}{l}\text { Observing other teachers' classes (peer } \\
\text { observation) }(n=257)\end{array}$ & $34 \%(n=87)$ & $41 \%(n=105)$ & $20 \%(\mathrm{n}=53)$ & $3 \%(n=8)$ & $1 \%(\mathrm{n}=2)$ & $1 \%(n=2)$ \\
\hline $\begin{array}{l}\text { Being observed by other teachers/by an } \\
\text { English language specialist }(\mathrm{n}=256)\end{array}$ & $36.5 \%(n=94)$ & $37.5 \%(\mathrm{n}=96)$ & $19 \%(n=49)$ & $4 \%(n=10)$ & $2 \%(n=5)$ & $1 \%(n=2)$ \\
\hline $\begin{array}{l}\text { Getting support from more experienced } \\
\text { teachers } \\
\text { (mentorship) }(\mathrm{n}=257)\end{array}$ & $52.5 \%(\mathrm{n}=135)$ & $32 \%(n=84)$ & $10 \%(n=25)$ & $3 \%(n=7)$ & $1.5 \%(n=4)$ & $1 \%(n=2)$ \\
\hline
\end{tabular}

$\mathrm{n}=$ number of teachers

\subsection{Relationships between Socio-Demographics, Teachers' PD Needs and Interest}

We observed statistically significant relationships between the teachers' reported needs for most of the instructional skills and their socio-demographics. 
Teachers' age was related to varying level of teachers' PD needs. A large number of teachers aged between 21 and 29 years old reported their PD needs ranged from moderate to very high compared to the teachers in the other age-groups $(\mathrm{p}<0.05)$. This relationship was observed for the five instructional skills, namely, maintaining teachers' language skills, student assessment, planning lessons and units, practice of ELT methodologies, and applying ELT standards.

Similarly, teachers' PD interest was also shown to be related to their age. A large number of teachers aged 21-29 years old reported their PD interest ranged from moderate to very high compared to the teachers in the other age-groups ( $\mathrm{p}<0.05)$. This relationship was observed for the three PD activities: participating in in-school or district sponsored-workshops/PD activities and qualification programs (e.g., degree program), collaborating with other teachers, and getting support from more experienced teachers (mentorship).

Compared to primary and higher education level teachers, a larger number of secondary school teachers reported their PD needs were either moderate or very high $(\mathrm{p}<0.05)$ for the six instructional skills, namely, content and performance standards in main subject, maintaining teachers' language skills, classroom management, planning lessons and units, practice of ELT methodologies, and teaching students with special needs.

Compared to novice teachers, a larger number of experienced teachers reported their PD needs ranged from moderate to very high $(\mathrm{p}<0.05)$ for the eight PD activities, namely, maintaining teachers' language skills, student assessment, classroom management, planning lessons and units, practice of ELT methodologies, applying ELT standards, teaching students with special needs, and student counselling.

\subsection{Barriers to Teachers' PD}

\subsubsection{Environmental Factors}

According to the participants, key barriers to TPD programs were governmental policies resulting in inadequate support and incentives to encourage the pursue of teachers' professional development programs.

One of the participants explained:

“...lack of suitable educational policy, lack of trainings and support to the teachers by authorised agencies, lack of observation and evaluation from the government political hindrance, not hiring the teachers in a competitive way, judgemental system to teachers' daily work."(Male teacher, public school)

In addition, institutional lack of interest in training teachers to help them better manage classes, research work and other activities was noted down, as one participant elaborated:

"I have been teaching English language at college level for last 10 years. Recently, I have been appointed as a government secondary level English language teacher. But besides NELTA supported programs, I haven't participated in any training. Government or any other institutions hardly emphasize training for novice teacher. I haven't come across any organization offering training related to classroom management, action research or other programs for ELT teachers." (Female teacher, public \& private schools)

Participants also noted that implementation of TPD programs has not addressed teachers' real needs of the teachers since they largely lack local context. The implementation of the programs was said to be unresponsive to match actual needs, as one of the participants critiqued:

"Often professional development activities are organized following top-down approach. Actually, these programs are organized formally to complete their expense allocated to teacher activities in a fiscal year. The actual needs and issues of a teacher are not addressed at all" (Male teacher, public school).

Country's geography and accessibility of the TPD programs to rural teachers were cited to be additional challenging factors in pursuing the programs in Nepalese context. For instance, one of the participants described:

"The ELT professional development programs are only city-centred, as there are often opportunities available for English language teachers to grow professionally. However, there are none such opportunities in remote areas. The course designers (of TPD) do not have any idea about the standard of the English teachers teaching in remote areas who still use the same approach which the teachers of English used to practice decades ago. The programs largely ignore urban rural differences - for instance, teachers from rural Nepal and those from urban settings have been offered same trainings." (Male teacher, public \& private schools)

Similarly, some participants shared similar views highlighting lack of basic needs for learning and teaching. One participant shared: 
"Most of the English language teachers work in remote areas, where access to good transportation, communication and the Internet are difficult. The teachers are not much aware of any trainings and seminars for their professional development." (Female teacher, private school)

Multicultural and multi-lingual aspect of the country also seems to be a barrier to TPD programs and their potential benefits in translating both students' and teachers' language practices at school settings. Participants mentioned that some teachers seem to be hesitant to speak in English at schools and elsewhere.

One of the teachers said:

"Most of the English language teachers hesitate to speak English outside of classroom setting. Another main challenge for English language teachers is to encourage their learners to use English not only outside of classrooms but also in school/college premises." (Male teacher, public school)

Participants also shared that students from public schools generally seem to have a limited interest in practicing English language. A teacher said:

"Generally, the students from public schools do not prefer to speak in English language and most of teachers too do not have enough resources and skills to support students to speak English." (Female teacher, private school)

\subsubsection{Institutional Factors}

At the institutional level (public and private schools), a limited resource in terms of funding, technology and time allocation for TPD activities, was reported to be a key barrier to TPD. A large number of teachers mentioned that lack of teaching materials and training, attractive salary, incentives, and financial support were their main perceived barriers to TPD.

A participant pointed out that incentives and resources are hindrances to TPD, he elaborated:

"Teachers often do not get chance to take part in any kind of trainings, get financial support from schools to attend trainings, ...the challenges they often face are lack of incentive, time, and teaching technologies (e.g., ICT facilities)..." (Male teacher, public \& private schools)

Also, a similar view was shared by a participant from private school:

"As teachers teaching in private schools, we are generally paid low salary, and we do not get any opportunity to take part in any professional development programs supported by schools." (Female teacher, private school)

Two key barriers to TPD in terms of institutional and educational policies were also noted. First, support to teachers for attending their professional development was said to be limited. Second, lack of local institutional support to implement knowledge gained through TPD into classroom practice was also noted.

One of the participants said:

“...lack of workshops or trainings and non-supportive behaviour of school administration are barriers to an on-going TPD program. Some teachers repeatedly attend so many workshops/professional development activities but there not any knowledge translation culture after attending such programs." (Female teacher, private school)

The teachers also indicated that most of the private institutions in Nepal show a limited interest in TPD programs and there are not any incentives for teachers when they attend the trainings in the weekends.

Many private school teachers had similar views but one of them summed it up as:

"Educational institutions are hesitant to realise the importance of a teacher's professional development. The institutions which consider TPD as an essential thing want their teachers to go to such seminars on weekends so that the institution does not have to employ any extra teacher to cover the regular one. As a result of such practice, most of the teachers refuse to attend such TPD programs, as they think they also need at least one day off in a week after working hard for six days in a row. (Female teacher, public \& private schools)

\subsubsection{Personal Factors}

The main personal challenges to TPD were said to be lack of interest, knowledge, and financial resources of EFL teachers. 
One of the participants shared that teaching is not done with much interest thus TPD is much more essential and further added:

"Firstly, most of the teachers in Nepal are in teaching profession with not much interest. For such teachers, professional development activities are so important that could change their perception. Secondly, the teachers who are interested in teaching profession and are teaching with great interest are having hard time to make their teaching effective due to lack of teaching materials, technology, collaboration among fellow teachers, support from senior teachers, connection with national and international teacher associations and organizations..." (Female teacher, private school)

They critiqued teachers lacking knowledge about using recent technology along with not being updated enough to bring new ideas thus making it a challenge for professional development.

One of the participants said:

"Most of the teachers do not have knowledge about recent techniques, methods and approaches. They are not familiar with recent technologies and do not know how to use a multimedia system even if it is available to them. Most of the teachers are not associated with any kind of professional networks and hence may miss out bringing new ideas in their classroom teaching." (Male teacher, private school)

According to some participants another challenge is the financial burden caused due to attending such trainings which makes them to spend a big amount of their monthly salary.

One of the participants said:

"For the teachers like me, low economic status is the barrier. While coming to Kathmandu to attend a conference like NELTA from my hometown which is bit far away from the capital city, I have to spend around 15,000 Nepalese rupees minimum, which is a huge part of my monthly salary hence I have to plan in advance whether I can manage attending the conference." (Male teacher, public school)

\subsection{Enablers of TPD}

\subsubsection{Environmental Factors}

The participants highlighted six key environmental enablers such as a system to monitor and evaluate teaching skills, providing due recognition to better performing institutions, promoting paid trainings and workshops (activity based), increasing focus on rural-based TPD, use of information and communication technologies (ICT) in the schools, and a separate funding for TPD.

The need of trainings and workshops (activity based) was focused by all the participants, especially in rural Nepal along with, providing allowances to the teachers which will encourage teachers to attend workshops and training programs.

One of the participants put it as follows:

"Government should provide sufficient teacher professional development trainings, undertake regular monitoring and evaluation programs; further, the government should reward or inspire the English language institute or association for its good deeds." (Male teacher, public school)

The teachers also suggested that collaboration and mentoring programs, including via online programs, could help them in pursuing their ongoing TPD. In this regard, one of the participants shared:

“... Collaboration and mentoring should be emphasized; latest techniques and methods for English language teaching should be followed by teachers through workshops, trainings, the Internet or other online platforms. " [Male teacher, private school]

In addition to conduction of TPD trainings in the rural areas of Nepal, the use of ICT technology for rural-based teachers was perceived to be an enabling factor for pursuing TPD programs. One participant elaborated it:

"Professional development of English language teachers in rural areas need far more attention compared to those of urban. And the use of ICT technology in teaching English should be included in trainings and seminars for both rural and urban." (Female teacher, private school)

Participants also viewed a dedicated funding to be another enabler of TPD programs. One of the participants explained:

“...A separate fund should be allocated for organizing and providing trainings for a teachers' professional development. Such funds could also be utilised to organize expert visits to different educational institutions to provide with necessary support in the TPD area in regular basis." (Male teacher, public \& private schools) 


\subsubsection{Institutional Factors}

The participants suggested monitoring and evaluation body should be in the institutional system to find out whether the TPD programs are adequately implemented. According to them the main role for this can be played by principal, who plays a dual role.

One of the participants explained it:

"School headmasters are the key persons who could make significant difference in teachers' professional development. They are the academic as well as administrative leaders at school level where actual teaching learning activities take place. National level plans and policies alone can play no significant role unless there is effective monitoring, observation, inspection, supervision, and effective academic and administrative leadership at institutional level especially from the classrooms. Such a mechanism, if effectively implemented, could potentially bring visible changes in teaching and learning system." (Female teacher, public school)

Some of the participants emphasized establishing a culture of speaking English language in classroom to motivate learners. A participant said:

"Rules and regulations and different support systems should be established for using English language in Classroom. Teachers should be provided necessary trainings on regular basis to motivation them to do better. If possible, ELT teachers should be provided opportunities to work with native speakers of English language to further enhance their skills.' (Male teacher, public school)

Teachers also recognised that school administrative support and a dedicated funding on TPD were other enabling factors for the effective implementation of TPD. One of the participants said:

"There should be always proper coordination between teachers and administration of institution. Especially in government schools, a small fund should be organized for ELT teachers to manage some teaching learning materials on time. The administrators do not actually provide the materials on time, and they even do not utilize the fund for the real purpose." [Male teacher, public school]

\subsubsection{Personal Factors}

Participants opined about the need of self-motivated teachers to learn and teach new things.

One of the participants emphasised giving opportunities to the teachers but highlighted that the teachers should also be self-motivated to learn and teach.

A participant said:

"The teachers must be given opportunity to make them aware of the new methodologies, techniques and technologies in teaching...however, it is equally important for the teachers themselves to be motivated and interested to grow professionally." (Female teacher, private school)

The participants also recognised the potential use of social-networking and learning groups in harnessing learning and development. One of the participants opined:

"Teachers should be encouraged to learn English language more through social networking. They should put effort to learn from their colleagues and more experienced teachers." (Male teacher, public school)

Similarly, providing teachers with updated knowledge and skills on recent teaching methodologies was noted as another enabling factor for TPD. One of the participants explained:

"Teachers must be resource persons, they must be updated with the changing trend of education worldwide, and teachers must know about the recent teaching methodologies and techniques, teachers must know about the interest of learners." [Female teacher, public school]

\section{Discussion}

This study revealed high to very high TPD needs for ELT, as reported by more than two thirds of EFL teachers. A considerable proportion of Nepalese EFL teachers showed high PD needs for almost all skills (table 2). Likewise, very high PD needs were identified particularly for using information and communications technology, student counselling, using cooperative learning, and teaching students with special needs. These findings could be important to consider in view of any future PD programs aimed at Nepalese EFL teachers. 
A majority of EFL teachers' PD interests were found to be particularly for mentorship, taking part in conferences/seminars, and sponsored-workshops/PD activities in schools/districts, and participating in out-of-school workshops/courses. Interestingly, mentorship has been previously identified as one of the under-utilised forms of TPD in Nepal (Joshi et al., 2018). Similarly, Nepalese EFL teachers perceive conferences, seminars, and workshops as the primary strategies for their PD (Joshi et al., 2018). These activities often take place in sites outside of school; therefore, teachers are generally interested to travel and take advantage of building professional networks during these activities. This also means that teachers need to have enough resources (i.e., time and money) for their ongoing participation in these programs. Though a majority of EFL teachers have been provided with release time for PD activity participation, schools/districts could also consider providing them with some other means of incentives. The incentive may include adequate financial support, pay rise, onsite resource access and onsite workshop. Such forms of support may have positive impact in boosting teachers' engagement in their professional learning and professional development. It is obvious that some of these PD needs seem to relate to personal/interpersonal level, while the others to school and system level (Harris, 2000).

The study also identified some key barriers and enablers to TPD. There were a number of barriers (e.g., lack of suitable educational policy, trainings, funding, support from school administration, motivation, etc.) and enablers (e.g., funding, support from school administration, social networks, etc.) to TPD reported by the teachers. Some of the reported barriers to TPD, could in fact be enablers when available. For instance, funding and institutional support provided by government and schools for TPD, albeit identified as a barrier, when available enables the teachers' engagement in TPD programs. Unsurprisingly, lack of financial resources and institutional support was identified as key barriers to teachers' professional learning and development internationally (Dayoub \& Bashiruddin, 2012; the Bill \& Melinda Gates Foundation, 2014; NSW Education Standards Authprity, 2017; Mohan \& Chand, 2017). According to the quantitative data of our study, in addition to financial support, release time offered teachers, online resource access and onsite workshops were identified as key enabling factors for TPD in Nepal.

Notably, private school teachers seem to have limited opportunities, particularly in terms of their access to government supported TPD programs. Furthermore, rural-based teachers in Nepal found the delivery of TPD programs in major cities as a main challenge making them accessible or nearby locations. This finding is similar to what was reported elsewhere (e.g., NSW Education Standards Authority, 2017). For instance, teachers in regional, rural, and remote areas in the state of New South Wales, Australia were more challenged to access TPD programs compared to the teachers in major cities (NSW Education Standards Authority, 2017). This indicates the scope for local-(or school-) based TPD models to facilitate the better access to TPD programs for a larger number of rural-based teachers in Nepal.

The strength of the study include: i) a relatively large sample size representing participants from all over the country, and ii) use of mixed data to evaluate the and present the findings. Furthermore, the study included a larger proportion of private schools' teachers; this means our study also assessed and explored their PD needs and interests, which were largely unknown in Nepalese context. The limitation of the study includes that the study subjects were non-representative of entire EFL teachers in Nepal as it only studied those attending the NELTA conference.

The data presented in this study are important particularly for ELF teachers' professional learning and development in Nepal. The study highlights various teacher professional development issues that could form the basis and guidance for future PD programs. At times when ELT in Nepal needs appropriate policies and research (Aryal et al., 2016) on TPD, the findings of the present study inform the design of need- and evidence-based TPD programs and policies. Similarly, this study has presented some data that would help generate hypotheses and guide future research in this area. Future design and implementation of PD activities should therefore consider these findings in order to make the PD programs more accepted and contextualised in Nepal. Therefore, these data on EFL teachers' perceived needs, interests, and challenges to pursue TPD programs reported in this study have both important research and policy implications in Nepal. One of the avenues for future research could be to explore and characterise problems faced by male and female EFL teachers in their professional development. While the study was conducted in Nepalese context, it also contributes to the literature EFL teachers' PD needs and interests, enablers and challenges vis-à-vis developing countries in general.

\section{Conclusion}

The study showed that Nepalese EFL teachers have a high PD need and interest. Similarly, EFL teachers' PD needs vis-à-vis various specific instructional skills and PD interests for various PD activities range from high to very high. This study also identified specific PD needs and PD interests of the EFL teachers to be addressed. 
Lack of suitable educational policy, trainings, funding, support from school administration, motivation, etc. were identified as major challenges to TPD. Similarly, allocation of more funding, support from school administration, reinforcement of social networks, release time offered teachers, online resource access and onsite workshops were also cited to be enabling factors for pursuing TPD programs. Among the private school teachers, additional challenge was that many of the TPD programs run by the government were inaccessible to them. Our study also highlights several environmental, institutional and personal enabling and challenging factors in pursuing ELF teachers' professional development. Overall, this study concludes that Nepalese EFL teachers demonstrated a considerable need and interest in TPD despite experiencing several types of challenges.

\section{References}

Adhikari, M. (2011). Teacher development in the EFL contexts: Principles and strategies. Journal of Nepal English Language Teachers' Association NELTA, 16, 133-135. https://doi.org/10.3126/nelta.v16i1-2.6137

Anderson, C. A. (2008). A quantitative study of the perceived professional development needs of foreign language teachers employed in rural school districts within the state of South Carolina. Unpublished doctoral dissertation. Minneapolis, Capella University.

Aryal, A., Short, M., Fan, S., \& Kember, D. (2016) Issues in English Language Teaching in Nepal. In: Fan S., Fielding-Wells J. (Eds.), what is Next in Educational Research? Sense Publishers: Rotterdam. https://doi.org/10.1007/978-94-6300-524-1_14

Asian Development Bank (2017). Innovative Strategies for accelerated Human resource development in South Asia. Teacher Professional Development - special focus on Bangladesh, Nepal, and Sri Lanka. Retrieved $10^{\text {th }}$ January 2017, from https://www.adb.org/sites/default/files/publication/385091/teacher-professional-development-sa.pdf

Avalos, B. (2011). Teacher professional development in Teaching and Teacher Education over ten years. Teaching and Teacher Education, 27, 10-20. https://doi.org/10.1016/j.tate.2010.08.007

Badri, M., Alnuaimi, A., Mohaidat, J., Yang, G., \& Al Rashedi, A. (2016). Perception of Teachers' Professional Development Needs, Impacts, and Barriers: The Abu Dhabi Case. SAGE Open, 1-15. https://doi.org/10.1177/2158244016662901

Bharati, P. L., \& Chalise, S. (2017). Teacher Development: Strategies and Perception. The Saptagandaki Journal, 8, 69-78. https://doi.org/10.3126/sj.v8i0.18464

Blase, J., \& Blase, J. (1999). Leadership for staff development: Supporting the lifelong study of teaching and learning. GA: University of Georgia, College of Education, Department of Educational Leadership. (ERIC Document Reproduction Service No. ED 439 123).

Centre for Applied Linguistics (2010). Framework for quality professional development for practitioners working with adult English language learners. Washington, DC: p7.

Darling-Hammond, L., \& Richardson, N. (2009). Teacher learning: what matters? Educational Leadership, 66(5), 46-53.

Dayoub, R., \& Bashiruddin, A. (2012). Exploring English-language teachers' professional development in developing countries: cases from Syria and Pakistan. Professional Development in Education, 38(4), 589-611. https://doi.org/10.1080/19415257.2011.649986

Department of Education (2012). School Level Educational Statistics of Nepal: Consolidated Report 2011 (2068BS). Kathmandu, Nepal.

Gadella Kamstra, L. (2021). Improving EFL Teachers' Professional Experiences and Motivation: An Ecological Approach. Teaching English as a Second Language Electronic Journal (TESL-EJ), 25(1).

Garet, M. S., Porter, A. C., Desimone L., Birman B. F., \& Yoon K. S. (2001). What Makes Professional Development Effective? Results from a National Sample of Teachers. American Educational Research Journal, 38(4), 915-945. https://doi.org/10.3102/00028312038004915

Gnawali, L. (2016). English language teacher development through teacher associations: the case of NELTA. ELT Journal, 70(2), 170-179. https://doi.org/10.1093/elt/ccv086

Harris, B. (2000). A strategy for identifying the professional development needs of teachers: a report from New South Wales. Journal of In-Service Education, 26, 25-47. https://doi.org/10.1080/13674580000200109 
Joshi, K. D. (2010). Learning strategies of English language teachers for professional development (Unpublished MEd dissertation). Kathmandu, Tribhuvan University, Nepal.

Joshi, K. D., Gnawali, L., \& Dixon, M. (2018). Experience of Professional Development Strategies: Context of Nepalese EFL Teachers. Pakistan Journal of Education, 35(2), 53-78. https://doi.org/10.30971/pje.v35i2.547

Joshi, K. D., Gnawali, L., Giri, R. A., Dixon, M., \& Mayer, D. (2016). Professional development landscapes. The Proceedings of the first International Conference on Transformative Education Research and Sustainable Development. Dhulikhel, Nepal, October 21-23, 2016.

Khan, A. (2015). ICT enabled professional development of English teachers in Mumbai: A case study. An unpublished thesis (MEd program). Melbourne, the RMIT University.

Khandehroo, K., Mukundan, J., \& Alavi, Z. K. (2011). Professional Development Needs of English Language Teachers in Malaysia. Journal of International Education Research, 7(1), 45-52. https://doi.org/10.19030/jier.v7i1.3534

Kohl, A. G. (2005). The professional Development needs of K- 12 ESL and foreign language teachers: a descriptive study. Unpublished doctoral dissertation. Chapel Hill, the University of North Carolina.

Komba, W. L., \& Nkumbi, E. (2008). Teacher professional development in Tanzania: Perceptions and Practices. Journal of International Cooperation in Education, 11(3), 67-83.

Korkmazgil, S., \& Seferoğlu, G. (2013). Exploring Non-Native English Teachers' Professional Development Practices. Boğaziçi University Journal of Education, 30(1).

Leech, N. L., \& Onwuegbuzie, A.J. (2007). An Array of Qualitative Data Analysis Tools: A Call for Data Analysis Triangulation. School Psychology Quarterly, 22(4), 557-584. https://doi.org/10.1037/1045-3830.22.4.557

Leu, E. (2004). The patterns and purposes of school-based and cluster teacher professional development programs (EQUIP1 Working Paper No. 2). Washington, DC: USAID. Retrieved 10 $0^{\text {th }}$ January 2017, from https://pdf.usaid.gov/pdf_docs/pnadd973.pdf

Lin, Z. (2013). Language Teachers' Attitudes, Beliefs, Professional Knowledge, and Views on Professional Development: An Exploratory Study at a Preschool TEFL Setting. TESOL Journal, 4(1), 55-82.\# https://doi.org/10.1002/tesj.52

Luke, A., \& McArdle, F. (2009). A model for research-based State professional development policy. Asia-Pacific Journal of Teacher Education, 37(3), 231-251. https://doi.org/10.1080/13598660903053611

McAleavy T., Hall-Chen, A., \& Horrocks, S., et al. (2018). Technology supported professional development for teachers: lessons from developing countries. Education Development Trust.

Ministry of Education (2009). School Sector Reform Plan (2009-2015). Government of Nepal. Kesharmahal, Kathmandu, Nepal.

Ministry of Education (2010). Nepal: The country context. Ministry of Education and Sports, Government of Nepal.

Ministry of Education (2013). Teachers' Professional Development Handbook 2066 (in Nepali). National Centre for Educational Development, Sanothimi, Bhaktapur, Nepal.

Ministry of Education (2014). Nepal education in figures 2014 at a glance. Retrieved 14 ${ }^{\text {th June }} 2017$ from http://www.moe.gov.np/article/240/index.php

Ministry of Education (2016a). Education in Figures 2016. Retrieved $14^{\text {th }}$ May 2017 from http://www.moe.gov.np/article/711/nepal-education-in-figure-2016.html

Ministry of Education (2016b). School Sector Development Plan, Nepal, 2016-2023. Kathmandu: Ministry of Education, Government of Nepal.

Mohan, P. P., \& Chand, D. D. (2017). Teachers' Perceptions of the Impact of Professional Development on Learning and Teaching in a Developing Nation. Australian Journal of Teacher Education, 42(11), 18-33. https://doi.org/10.14221/ajte.2017v42n11.2

Moreno-Peral P., Conejo-Cerón S., \& Fernández A., et al. (2015). Primary Care Patients' Perspectives of Barriers and Enablers of Primary Prevention and Health Promotion-A Meta-Ethnographic Synthesis. PLoS ONE, 10(5), e0125004. https://doi.org/10.1371/journal.pone.0125004

NSW Education Standards Authority (2017). Enablers and Barriers to Initiating Professional Development. 
Retrieved

from https://educationstandards.nsw.edu.au/wps/wcm/connect/db70675f-02f5-41ef-95ae-62b7abe7aeb4/enablers-and -barriers-to-imitating-professional-learning.pdf?MOD=AJPERES\&CVID=

OECD Teaching and Learning International Survey (TALIS) (2008). Teacher Questionnaire. Retrieved $10^{\text {th }}$ January 2016 from http://www.oecd.org/edu/school/43081350.pdf

Ono, Y., \& Ferreira, J. (2010). A case study of continuing teacher professional development through lesson study in South Africa. South African Journal of Education, 30, 59-74. https://doi.org/10.15700/saje.v30n1a320

Pokhrel, T. R., \& Behera, S. K. (2016). Expectations of Teachers from Teachers Professional Development Program in Nepal. American Journal of Educational Research, 4(2), 190-194.

Popova, A., Evans, D. K., \& Breeding, M. E., et al. (2018). Teacher Professional Development around the World The Gap between Evidence and Practice. Policy Research Working Paper 8572. World Bank Group.\# https://doi.org/10.1596/1813-9450-8572

Richards J. C., \& Farrell, T. S. C. (2005). Professional development for Language Teachers - Strategies for Teacher Learning. New York: Cambridge University Press. https://doi.org/10.1017/CBO9780511667237

Shah, P. K. (2015). Nepalese EFL teachers' professional development: present practices, realities and looking forward. IATEFL Teacher Development SIG Newsletter, 73, 15-17.

Shams, F., Thapa, D., \& T. Parajuli. (2013). Teacher Management and Development in Nepal: A Strategy and Policy Document. Manila: Asian Development Bank.

Shrestha, P. (2008). ELT, ESP \& EAP in Nepal: whose interests are served? In: Krzanowski, Mark (Ed.), EAP and ESP in Developing Countries: State of Play vs Actual Needs and Wants (pp. 191-210). Canterbury: IATEFL (ESP SIG).

Shrestha, P. (2012). Teacher professional development using mobile technologies in a large-scale project: lessons learned from Bangladesh. International Journal of Computer-Assisted Language Learning and Teaching, 2(4), 34-49. https://doi.org/10.4018/ijcallt.2012100103

The Bill \& Melinda Gates Foundation (2014). Teachers Know Best. Teachers' Views on Professional Development. Retrieved from $\mathrm{http} / / \mathrm{k} 12$ education.gatesfoundation.org/resource/teachers-know-best-teachers-views-on-professional-developm ent/

Tsui, A. B. (2005). Expertise in teaching: Perspectives and issues. In K. Johnson (Ed.), Expertise in second language learning and teaching ( $\mathrm{pp}$ 167-189). New York: Palgrave Macmillan.\# https://doi.org/10.1057/9780230523470_9

Zein, M. S. (2016). Professional development needs of primary EFL teachers: perspectives of teachers and teacher educators. Professional Development in Education. https://doi.org/10.1080/19415257.2016.1156013

\section{Copyrights}

Copyright for this article is retained by the author(s), with first publication rights granted to the journal.

This is an open-access article distributed under the terms and conditions of the Creative Commons Attribution license (http://creativecommons.org/licenses/by/4.0/). 